\title{
Cicadas in the Hesychian Lexicon
}

\section{Elwira Kaczyńska \& Krzysztof Tomasz Witczak (University of Lodz)}

\begin{abstract}
Numerous Ancient Greek terms for 'cicada' are attested in the lexicon of Hesychius of Alexandria $\left(5^{\text {th }} \mathrm{C} . \mathrm{AD}\right)$; these are explained here from the morphological and etymological point of view. Some of them are dialectal items, representing Achaean (in Cyprus and Pamphylia)

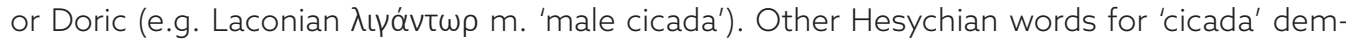
onstrate obvious features of Attic-lonic speech. New explanations are suggested for some of the rare appellatives belonging here, including Gk. dial. kíkous m. 'Young cicada' and kíkıৎ m. 'cicada'. Finally, possible motivation for the attested words is carefully discussed.
\end{abstract}

\section{Keywords}

Ancient Greek; cicadas; insects; Greek lexicography 


\section{Introduction}

Cicadas are easily recognized insects, mainly due to their large size ( 2 to 5 centimeters in European species) and their unique, loud sound. The latter was so pleasing to the ears of the Ancient Greeks that they called it "sweet" or "sweet-voiced". Even Plato (Phdr.

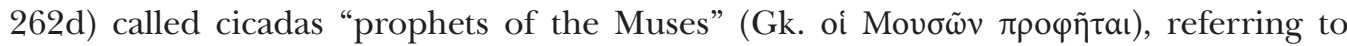
"their singing as a gift of the Muses" (Dihle 1967: p. 109). Cicadas live in both temperate and tropical climates, including the Mediterranean region. More than 2500 species of the cicada have been described, but commonly cicadas are treated as a unitary kind of insect. Only adult male cicadas produce the chirping noise, the loudest sound produced by any insect (up to $120 \mathrm{~dB}$ ). Female and young cicadas are mute.

Ancient Greeks were quite familiar with cicadas (Davies \& Kathirithamby 1986: pp. 113-133; Beavis 1988: pp. 91-103). They ate their larvae, especially to whet the appetite (Arist., HA V 30, 5; Ath. 133b). The most widespread term for this insect in Ancient Greek was $\tau \dot{\epsilon} \tau \tau \grave{\jmath}$ m. 'tree cricket, cicada' (Schenkl \& Brunetti 1991: p. 97, s.v. cicala). This word was used not only in Attic Greek and the Hellenistic koiné, but also in the epic language (including Homer, Il. 3.151, and Hesiod, Op. 580; Sc. 393).

However, the more precise Ancient Greek terminology for 'tree cricket, cicada' is abundant and interesting. Generally, Ancient Greeks distinguished three kinds of this winged insect: (1) male cicadas, which are larger and produce sound by vibrating drumlike tymbals - a pair of membranes located in the abdomen, (2) female ones, which are mute and smaller; (3) young or new-born cicadas. The nomenclature for 'cicada', known not only from different literary sources, but also from the non-literary Greek dialects, was registered in the well-known lexicon of rare or unusual words compiled by the end of the $5^{\text {th }}$ century by Hesychius of Alexandria.

In the present study, we shall discuss the words for 'cicada' attested in the Hesychian lexicon, recognizing their dialectal affiliation as a priority. Each gloss is therefore treated as a separate lexical unit, even if some discussed items have a common origin. If necessary, we shall also include other ancient sources in the discussion.

\section{Achaean (Cypriote and Pamphylian) terms}

No term for 'cicada' is attested in the Mycenaean texts. However, Hesychius of Alexandria quotes a number of appellatives taken from the Cypriote dialect and the Pamphylian one. The Achaean lexical data are the following:

2.1. The Cypriote word for 'small mute cicada' is attested in the following shape (HAL

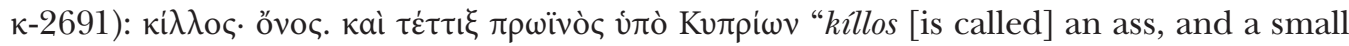
(born early, i.e. new-born) cicada by the Cypriotes" (Latte 1966: p. 478; cf. Davies \& Kathirithamby 1986: p. 129; Beavis 1988: p. 95). The Hesychian gloss in question shows two different meanings: 'ass' (Doric, according to Pollux 7.56) and 'cicada' (used by Greeks in Cyprus). Both nouns represent an innovative use of the adjective $\kappa \iota \lambda \lambda$ ' $\varsigma$ 'grey, ass-coloured' (Liddell \& Scott 1996: p. 951). The small cicada was named after the grey 
colour of its body (Gil Fernández 1959: p. 100; Wartelle 2000: p. 215; Beekes 2010: pp. 697-698; see Strömberg 1943: p. 100; 1944: pp. 11-12). ${ }^{1}$ It is worth emphasizing that the term for 'ass, donkey', ki $\lambda \lambda$ o, , also seems to represent a Cypriote innovation, cf. Mod. Gk. (Cypriote) к'i $\lambda \lambda_{\eta \varsigma}$ ['tyillis], also $\gamma \kappa i \lambda \lambda \eta \varsigma$ ['djillis] m. 'small ass / kleingewachsener Esel' (Andriotis 1974: p. 315; Chatziioannou 1996: p. 80; Giangkoullis 2002: p. 141).

2.2. A different Cypriote term is registered by Hesychius of Alexandria under the

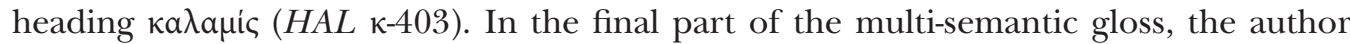

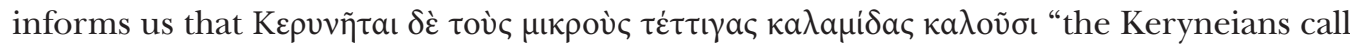

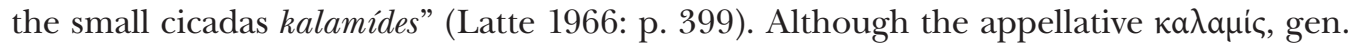
sg. $\kappa \alpha \lambda \alpha \mu i \delta o c$, is well-known in Ancient Greek, the meaning 'small (i.e. female or young) cicada' has to be treated as an innovation in the Cypriote dialect of Ancient Greek, as the ancient city of Keryneia (Gk. Kepúveı) was located on the northern coast of Cyprus.

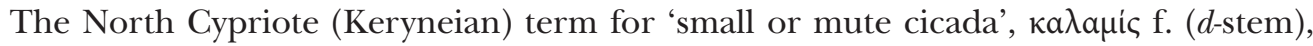

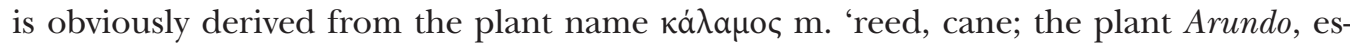
pecially giant cane, Arundo donax L.; sweet flag, Acorus calamus L.' (André 1985: p. 45) by means of the feminine suffix -i $\delta$-. Other names of cicadas (and other insects) seem

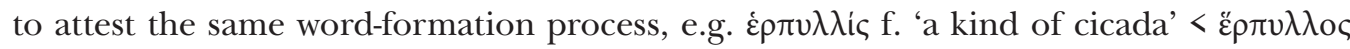

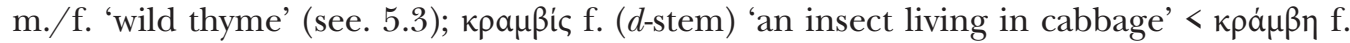
'cabbage, kail' (Gil Fernández 1959: p. 165).

It should be noted that Ancient Greek literary texts attest two other cognate forms:

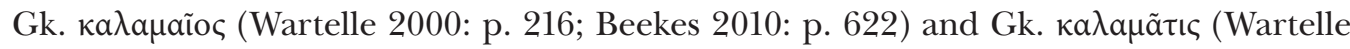
2000: p. 216). These items will be discussed below (see 5.6).

2.3. Hesychius of Alexandria informs us that the inhabitants of the town Side in Pam-

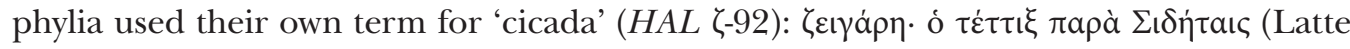
1966: p. 259; Brixhe 1976: pp. 84, 86, fn. 3). It is unclear whether the term in question was used by the Greek people of the town, the Pre-Greek population of Side, or both. It must be noted that two different languages, namely Pamphylian Greek and Sidetic (a native language of Anatolian origin), were used in the city of Side.

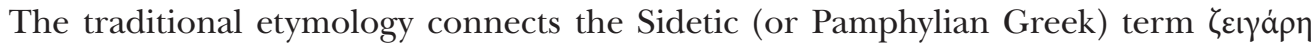

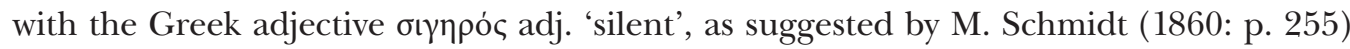
in his edition of Hesychius' lexicon. According to Schmidt, the gloss should be read as ¿ījapá. However, the Sidetic (or Pamphylian) noun could have been created by accent

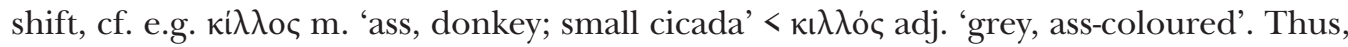
it must have denoted nothing other than 'the mute (female) cicada'.

Gil Fernández (1959: p. 126) believes that the gloss belongs to the Pamphylian Greek idiom, not excluding the possibility that it may be a borrowing from a Meditteranean substratum, like Lat. č̌cāda f. 'cicada, tree cricket' (cf. Niedermann 1919: p. 80; Alessio 1954: pp. 94-95). He accepts Metri's hypothesis that the initial $\zeta$ - appears in the place

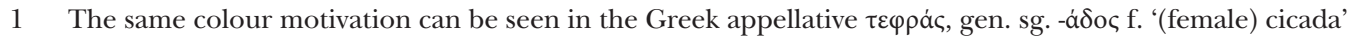
(Ael., $N A$ X 44). It derives from the Greek adjective $\tau \varepsilon \varphi \rho$ ó 'grey, ash-coloured' by means of the feminine

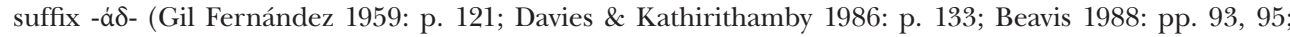

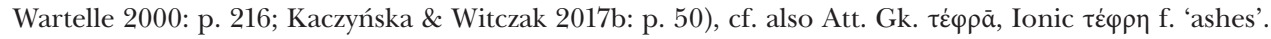


of a guttural stop, as in the Cypriot dialect (Metri 1954: p. 101)². Gil Fernández (1959: p. 126) treats it as a substratal phenomenon ("un fenómeno de substrat"). Dressler (1965: p. 185) presents a different point of view, according to which the Sidetic word in

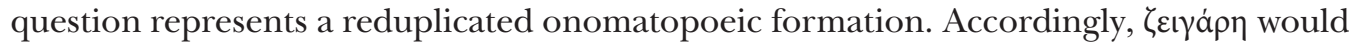
represent a "Mittelmeerwort" and derive from an alleged archetype * $k \bar{\imath} \iota \bar{a} d \bar{a}$ (probably lenited to [gi(:)ga:ða:] and [dzi(:)ga:ra:] in Sidetic), also seen in Latin č̆cāda f. "cicada, cricket' (de Vaan 2008: p. 112) and some Romance languages, e.g. Italian cicāla, Provencal cigala (> French cigale), Mozarabic chikala, Spanish cigarra, dial. chicharra 'cicada' (Meyer-Lübke 1935: p. 180).

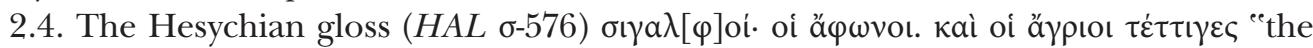
silent (people), and the wild cicadas" (Schmidt 1862: p. 27; Hansen 2005: p. 287; cf. also Gil Fernández 1959: p. 126; Dressler 1965: p. 185; Davies \& Kathirithamby 1986: p. 133; Beavis 1988: p. 95) should be treated as purely Pamphylian. It is evidently related to the

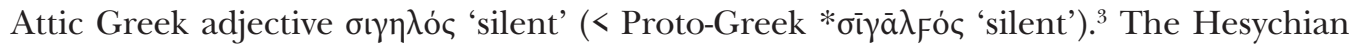
heading in question undoubtedly contains the Pamphylian phoneme $\varphi$ representing an

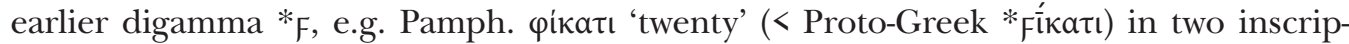
tions from Aspendos (Thumb \& Scherer 1959: p. 184-185; Brixhe 1976: pp. 141, 201,

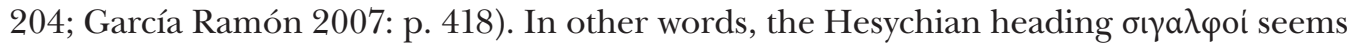

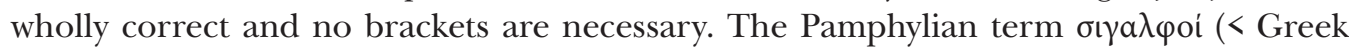
${ }^{*} \sigma \bar{\imath} \gamma \bar{a} \lambda_{F}$ fi pl. 'silent') evidently refers to the mute cicadas, i.e. female or new-born ones. ${ }^{4}$

\section{Attic-Ionic words}

3.1. The Attic-Ionic term for 'male cicada' is attested in the following Hesychian gloss

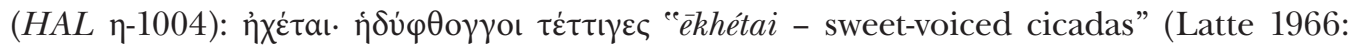

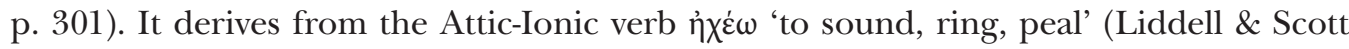

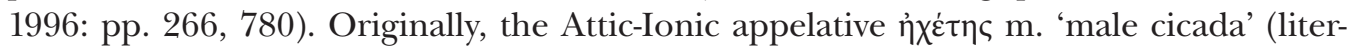
ary 'the chirper') represented a descriptive epithet of the cicada (Gil Fernández 1959: p.

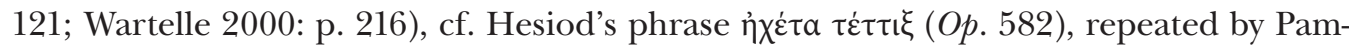

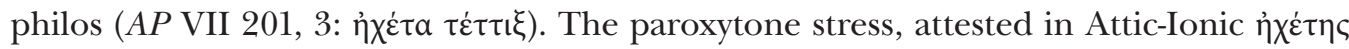

2 It is worth emphasizing that the question of whether Gk. $\gamma[\mathrm{g}]$ can be rendered as $\zeta[\mathrm{cz}]$ or $[\mathrm{z}]$ in the Ancient Cypriot dialect is much disputed, e.g. Gk. Cypr. a-za-ta-i [azat ${ }^{\mathrm{h}} \bar{i}$ ] dat. sg. f. (= Gk. Att. ảya $\left.\theta \tilde{n}\right)$

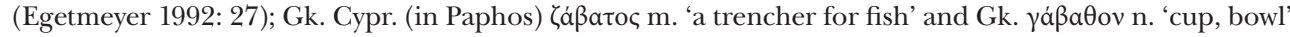
(Beekes 2010: 253). The most recent literature on this subject generally takes a sceptical view (Egetmeyer 2010: 184, 188-190).

3 Hesychius of Alexandria demonstrates other Pamphylian glosses with the phoneme $\varphi(<$ Proto-Greek $* F)$,

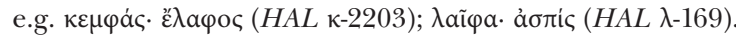

4 Note additionally that Gk. oíyıv n. 'small (mute) cicada' (Gil Fernández 1959: p. 126; Dressler 1965: p. 185; Davies \& Kathirithamby 1986: p. 133; Beavis 1988: pp. 94-95) is a diminutive form related to the verb

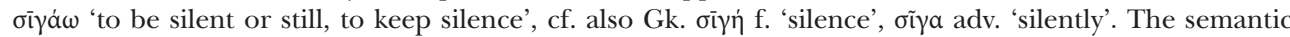
aspects of the suggested derivation are obvious: small cicadas (i.e. female and young ones) are mute by their nature. 


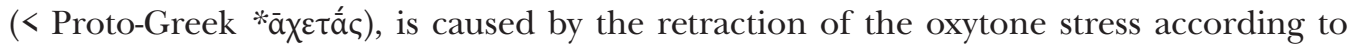
Bartoli's accentual law. ${ }^{5}$

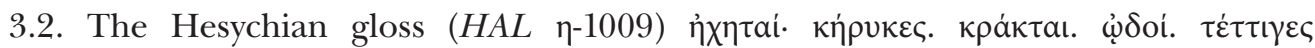

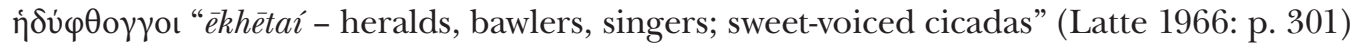

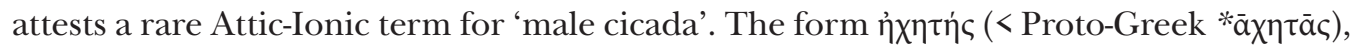
which derives regularly from the verb $\eta \chi \chi \dot{\varepsilon} \omega$, is not found in Ancient Greek literature, see Gil Fernández (1959: p. 122).

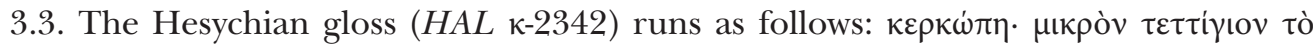

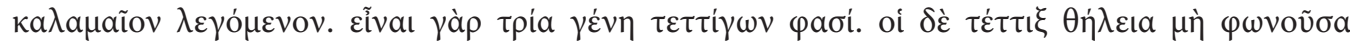
(Latte 1966: p. 465) "kerkópé is a small cicada called also kalamaĩon. There are, as some say, three kinds of cicadas. Others say that it denotes a female, non-chirping cicada".

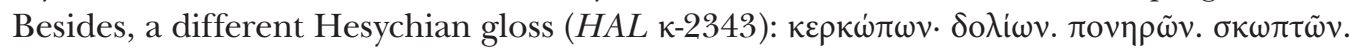

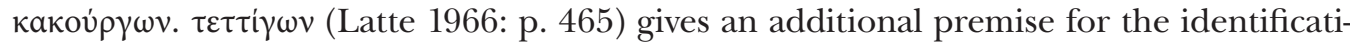

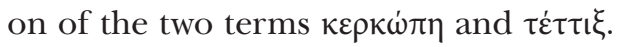

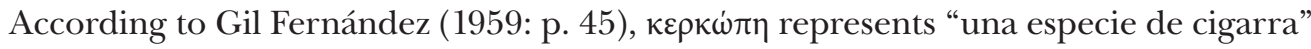
(see also Davies \& Kathirithamby 1986: pp. 131-132; Beavis 1988: pp. 93-95). The noun, which evidently refers to 'the female cicada', means nothing other than 'an insect similar to a locust' or 'a long-tail insect, i.e. a cicada with a long abdomen' (Kaczyńska \& Witczak

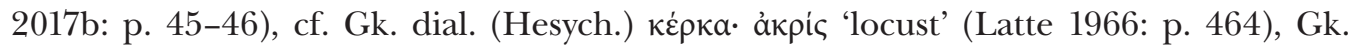
кย́ркоц m. 'tail (of an animal)' (Beekes 2010: p. 679). It cannot be excluded that all of the terms in question are of Pre-Greek origin.

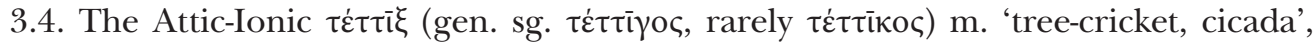

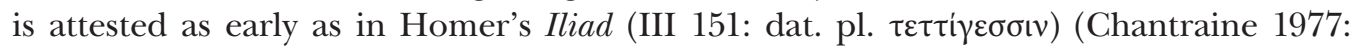

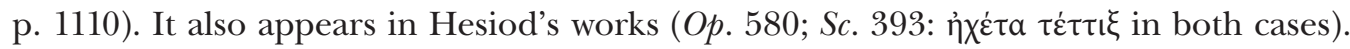
Hesychius of Alexandria uses the common appellative $\tau \dot{\varepsilon} \tau \tau \grave{\xi}$ in many lemmas (Kaczyńska \& Witczak 2017b: p. 44). ${ }^{6}$

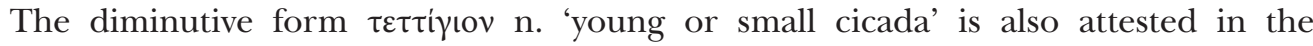

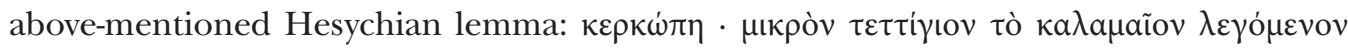

5 A different (probably West Greek) appellative for 'adult male cicada', $\lambda \bar{\alpha} \kappa \varepsilon ́ \tau \bar{\alpha} \varsigma$ m. (Ael., NA X 44: кaì

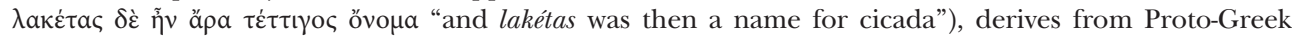

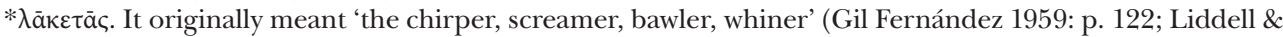
Scott 1996: p. 1025; Davies \& Kathirithamby 1986: pp. 132-133; Beavis 1988: p. 93). The word in question derives from the Doric verb $\lambda \bar{a} \kappa \dot{\varepsilon} \omega$ (= Attic-Ionic $\lambda \eta \kappa \dot{\varepsilon} \omega$ ) 'to crack, crackle' (Liddell \& Scott 1996: pp. 1025,

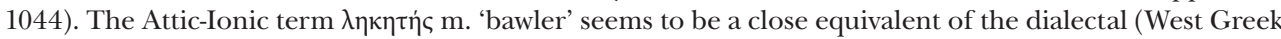
or Doric) name for 'adult male cicada' (Gil Fernández 1959: p. 122; Wartelle 2000: p. 216; Kaczyńska \& Witczak 2017b: p. 49).

6 Hesychius of Alexandria also introduces three successive headings containing the same lexeme (cf. Han-

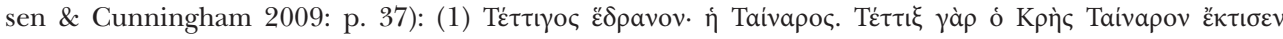
"Tettigos hedranon (i.e. Tettix' seat) [refers to] the city of Tainaros, as the Cretan named Tettix (i.e. Cicada)

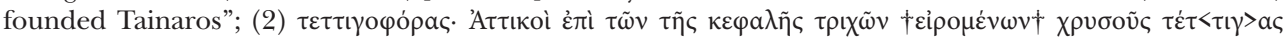
"tettigophóras - the Attic people wore golden cicadas in the head's hair". According to Aristophanes (Eq. 1331), it was an epithet of rich Athenians, who before Solon's times wore golden cicada-shaped hair-pins as an emblem of their claim to being native in Attica (Liddell \& Scott 1996: p. 1783; Montanari 2003: p.

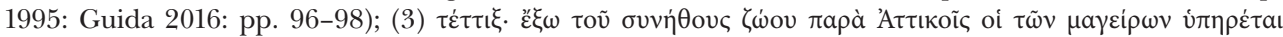

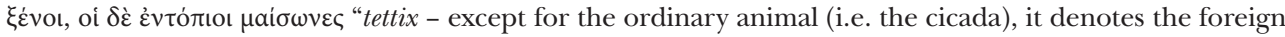
assistants of cooks in some Attic authors; others say that it refers to the local (i.e. Athenian) native cooks". 


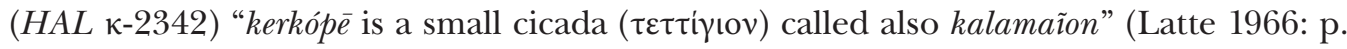
465).

Almost all Ancient Greek dialects attest the same term $\tau \dot{\varepsilon} \tau \tau \bar{\imath} \xi$, gen. sg. -ījoৎ (and rarely -ікоৎ) $\mathrm{m}$. 'tree cricket, cicada', also metaphorically 'a hair-pin with the shape of a cicada'

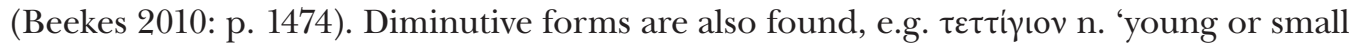

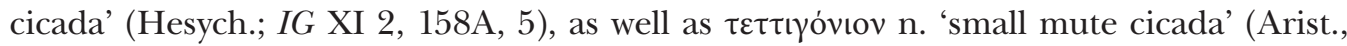
HA 532b 17) (Liddell \& Scott 1996: p. 1546; Montanari 2003: p. 1995). An onomatopoeic origin of the widespread appellative $\tau \dot{\varepsilon} \tau \tau \bar{l} \xi$ cannot be disproved. Note that the Modern

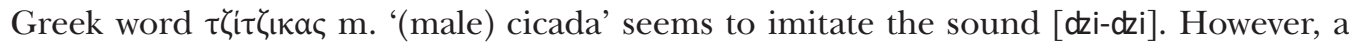
hypothetical Pre-Greek origin of the appellative in question appears to be equally wellfounded.

In our opinion, the common Ancient Greek name for 'cicada' derives from the adjec-

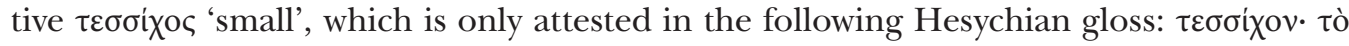

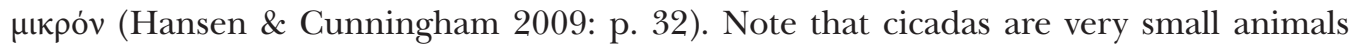
in comparison with amphibians, reptiles, birds or mammals ${ }^{7}$. Both the common noun denoting 'male cicada' and the extremely rare adjective with the meaning 'small' seem to represent a borrowing from a Mediterranean substratum (Kaczyńska \& Witczak 2017b: p. 45).

\section{Doric (Laconian and Eleian) names for 'cicada'}

4.1. The Laconian term for 'adult male cicada' is registered in Hesychius' lexicon (HAL

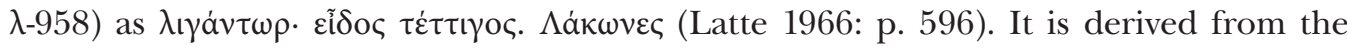

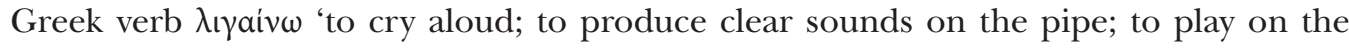
pipe; to sing' by means of the agentive (masculine) suffix *-tōr and it denotes the adult male chirping (i.e. singing) cicada (Gil Fernández 1959: p. 121; Davies \& Kathirithamby 1986: pp. 117, 133; Beavis 1988: p. 95; Wartelle 2000: p. 216).

4.2. Hesychius of Alexandria registers the Eleian word for 'adult male cicada' in the

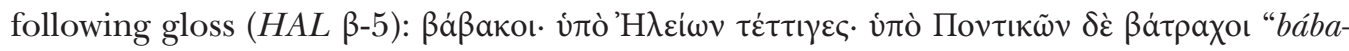
koi - [so are named] cicadas by the Eleians, frogs by the Pontic Greeks" (Latte 1953: p. 304; Cunningham 2018: p. 411). Both male cicadas and frogs produce an intensive noise (Wartelle 2000: p. 218). Modern Greek lexical data, especially Macedonian Greek (in Kozani) ßáßaкovৎ m. 'frog / Frosch' (Andriotis 1974: p. 170; Kaczyńska \& Witczak 2017a: p. 112), show that the Hesychian gloss in question documents a dialectal differentiation in the Greek language world as early as in the ancient times. Shipp (1979: p. 122) correctly stresses that the gloss in question cannot be a fictitious creation of Ancient Greek grammarians, as it is confirmed by Modern Greek dialects.

Beekes (2010: p. 189) derives the Eleian name for 'cicada' from the rare noun $\beta \dot{\alpha} \beta a \xi$ m. 'chatterer' (attested in Archilochus, fr. 33; Lyc. 472) and the verb $\beta a \beta a \dot{\alpha} \zeta \varepsilon$ เv 'to speak

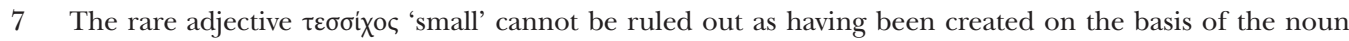
$\tau \dot{\varepsilon} \tau \tau \bar{\zeta}$ 'cicada'. If so, the direction of derivation may be quite opposite. 


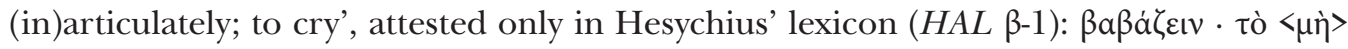

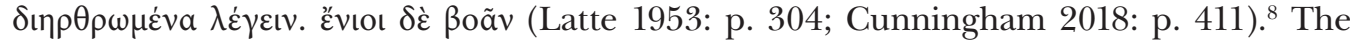
Hesychian gloss may be easily explained on the basis of the Indo-European root * $u a \bar{a} b$ - 'to cry' (< PIE. * $u e h_{2} b$-), which is perfectly well-attested in Germanic, Baltic and Slavic languages, cf. Goth. wōpjan 'to call loudly, call out', OSax. wōpian, OHG. wuofan 'to bewail', OE. wēpan 'to weep'; Latv. vābît 'to entice, summon to judgment'; OCS. vabiti 'to summon, entice', Pol. wabic 'to decoy, allure, lure' (Trautmann 1923: pp. 336-337; Pokorny 1959: p. 1109; Lehmann 1986: p. 409; Derksen 2008: pp. 511-512).

A different etymology connects Anc. Gk. dial. (Eleian, Pontic) ßáßaкo pl. 'cicadas; frogs' with the Indo-European term for 'frog, toad', cf. OPruss. gabawo f. 'toad', OChSl. $\check{z} a b a$ 'frog', Russ. жaбa f. 'toad', Pol. żaba f. 'frog', MDu. quappe, quabbe 'eelpout', EDu. quabbe 'eelpout, gudgeon; frog' < IE. * * $g^{\prime \prime} e \bar{e} h$-, zero-grade * $g^{\prime \prime} a b h$ - (Pokorny 1959: p. 466; Kroonen 2013: p. 314). In this case we can assume the semantic change of 'frog' to 'cicada': as noted above, frogs, like adult male cicadas, produce a loud sound.

\section{Other particular or dialectal terms}

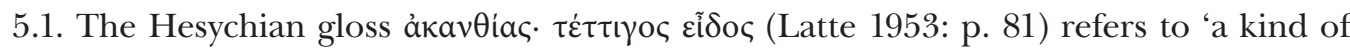
cicada' (Gil Fernández 1959: pp. 165-166: "un nombre de la cigarra”; Beavis 1988: p. 94; Liddell \& Scott 1996: Suppl., p. 13: "cicada”) or perhaps 'a kind of grasshopper' (Abramowiczówna 1958: p. 62: "gat. konika polnego"; Montanari 2003: p. 104: "specie

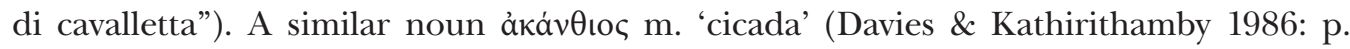
130; Adrados 1989: p. 108) was earlier used by Claudius Aelianus in his work entitled $D e$ natura animalium (NA X 44).

The etymology of the noun ảkavtiạ is clear (Beekes 2010: p. 48). Gil Fernández (1959: p. 166) correctly connects it with prickly plants (especially thistles) called ökav $\theta \alpha \mathrm{f}$. and

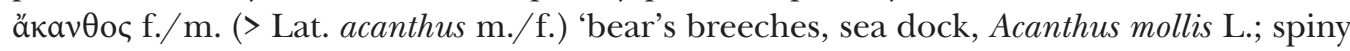
bear's breeches, Acanthus spinosus L.; a kind of mimosa, Acacia L.' (André 1985: p. 2), suggesting that the term refers to cicadas living among the thistles ("El sentido primitivo sería el de «(cigarra) de los cardos»"). This explanation seems acceptable from the semantic point of view.

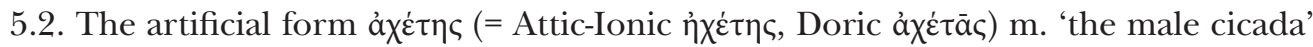
is mentioned by Hesychius of Alexandria in the following gloss (HAL a-8850): áxítnऽ .

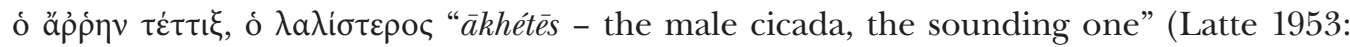
p. 299; Cunningham 2018: p. 403). The term was also used as an epithet of the cicada by Archias of Antioch (Aulus Licinius Archias, ca. 120-61 BC) in one of his epigrams

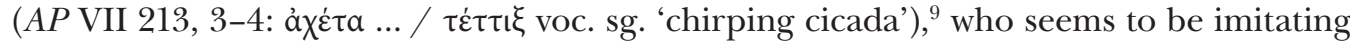

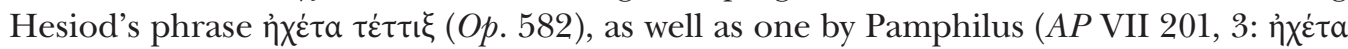

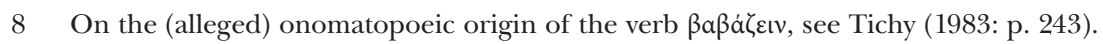

9 See e.g. Ebener (1981: p. 61). In one of his epigrams (AP VII 196), Meleager of Gadara uses an innovative

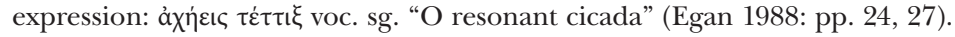


$\tau \dot{\tau} \tau \tau \mid \xi)$. Archias' ảx $\dot{\tau} \tau \alpha$ represent a dactylic foot $(\dot{-} \cup \cup)$ and contains the long vowel $\bar{\alpha}$ [a: in the initial position. The term in question represents an adjective with the meaning 'clear-sound, musical, shrill, chirping' (it can refer to reed, swans and cicadas), as well as a noun denoting 'the adult male cicada'. The correct (not-Ionic) form should be given

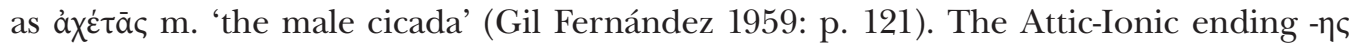
was reproduced by the author of the glossary according to the norms of the Hellenistic

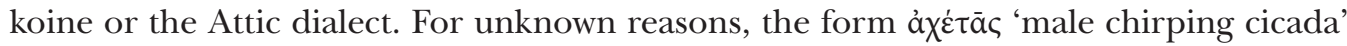
is preferred by Aristotle in his History of Animals (HA 532b 16, 556a 20). The exact AtticIonic equivalent $\eta x \chi \dot{\varepsilon} \tau\rceil \varsigma$ is well-entrenched in Ancient Greek literature (Gil Fernández 1959: pp. 121-122; Wartelle 2000: p. 216), see 3.1 (and 3.2) above.

The verb ảx $\dot{\varepsilon} \omega$ (with the initial long vowel $\bar{\alpha}$ [a:]) is commonly treated as the Doric counterpart of the Attic-Ionic verb $\eta \chi \chi \dot{\varepsilon} \omega$ 'to sound, ring, peal' (Liddell \& Scott 1996: pp. 266, 780) < Proto-Greek ${ }^{*} \bar{\alpha} \chi \mathcal{\varepsilon}(\omega$. . The closest equivalent is attested in Lat. vāgiō, vāgìre 'to wail, to cry' (Beekes 2010: p. 528; de Vaan 2008: p. 651).

5.3. The Hesychian gloss (HAL ع-5992) $\varepsilon \rho \pi u \lambda \lambda i c \cdot \tau \dot{\varepsilon} \tau \tau ı \xi$ (Latte 1966: p. 198) is not attested in Greek literary texts. It is frequently glossed as 'cicada' (Davies \& Kathirithamby 1986: p. 131; Beavis 1988: p. 95) or 'grasshopper' (Beekes 2010: p. 463). Strömberg (1944:

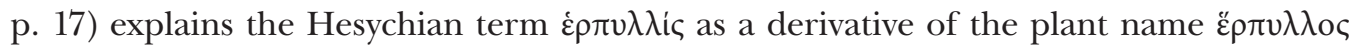
m./f. 'wild or creeping thyme, Thymus serpyllum L.' (André 1985: p. 122), also 'tufted thyme, Thymus sibthorpii Benth' (Liddell \& Scott 1996: p. 691). Gil Fernández (1959: p. $165)$ accepts Strömberg's etymology. Indeed, the feminine suffix -i $\delta$ - was frequently used for deriving names of insects (Gil Fernández 1959: pp. 165-166). See also 2.2.

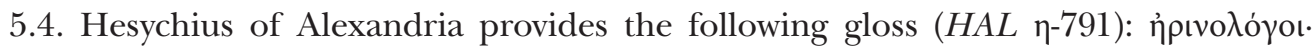
oi $\tau \dot{\tau} \tau \tau i \gamma \varepsilon \varsigma$ m. pl. 'cicadas' (Latte 1966: p. 294), originally 'early talking' (cf. Gk. $\tilde{\eta} \rho \mathrm{adv}$. 'early') or 'talking in spring' (cf. Gk. †̉ member of the compound n’ the Greek verb $\lambda \dot{\varepsilon} \gamma \omega$ 'to say, speak, call'.

5.5. Another Hesychian gloss (HAL $\eta-941)$ is commonly marked with the so-called

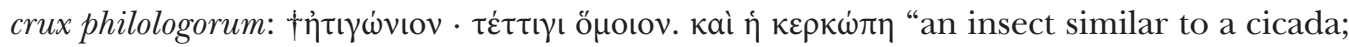
Also, the small mute cicada" (Latte 1966: p. 198). It is obvious that the Hesychian form

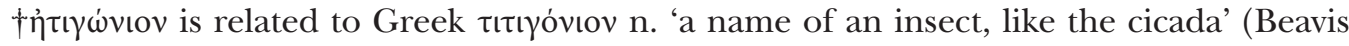
1988: p. 94; Beekes 2010: p. 1488), ${ }^{10}$ but the exact relationship appears obscure. It is pos-

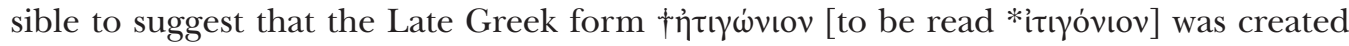

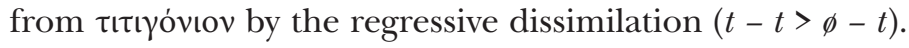

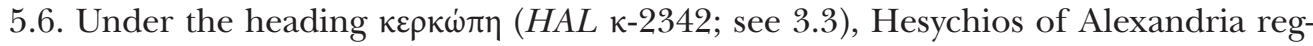

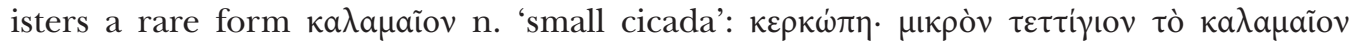
$\lambda \varepsilon \gamma o ́ \mu \varepsilon v o v . ~ " k e r k o ́ p e \overline{~ i s ~ a ~ s m a l l ~ c i c a d a, ~ a l s o ~ c a l l e d ~ k a l a m a i ̃ o n " ~(L a t t e ~ 1966: ~ p . ~ 465 ; ~ B e a v i s ~}$

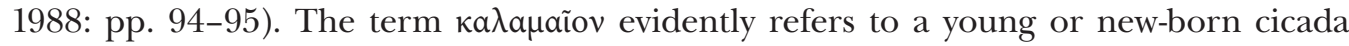

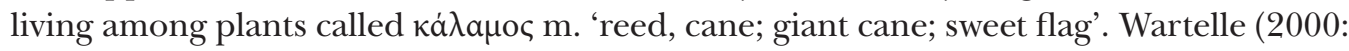

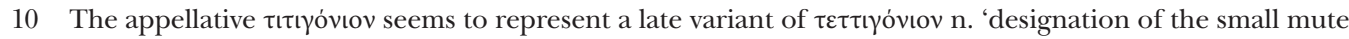
cicada' (see 3.4). It is worth mentioning that Zenodotus of Alexandria (Schol. A Il. 2. 314), the famous

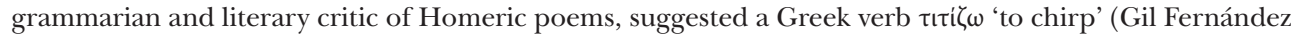
1959: p. 130; Beekes 2010: p. 1488). Note, however, that small (young or female) cicadas are mute. 


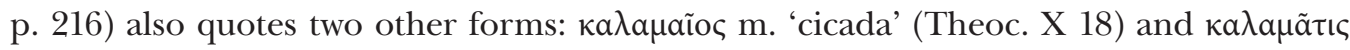
f. 'id.' (AP VII 198). The derivative nouns in question are built by means of the suffixes

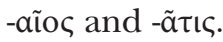

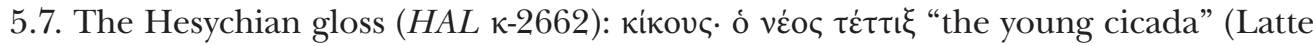
1966: p. 477; cf. Davies \& Kathirithamby 1986: p. 132; Beavis 1988: p. 95). According to Alessio (1954: p. 95), this Hesychian gloss represents "[u]na forma più vicina" to Lat. č̆căda. Both of these terms should, according to the Italian linguist, be treated as two independent loanwords of Mediterranean origin ("di origine mediterranea"). Gil Fernández (1959: pp. 126-127) believes that the term for 'young cicada' is of onomatopeic origin, like Lat. č̆cāda. A similar position is that of Dressler (1965: p. 185). The onomatopeic origin of Gk. dial. kikous is hardly acceptable, as the young cicada is mute. Szemerényi (1988: pp. 132-134) tries to prove that Lat. č̆cāda f. is not borrowed from a Mediterranean source. In his opinion, it represents a purely Hellenic loanword in Latin,

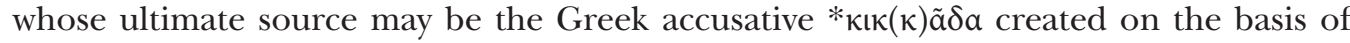

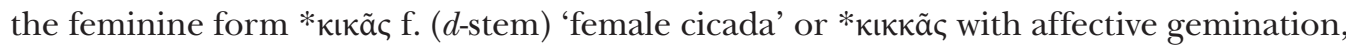
cf. Gk. (Hesych.) кíкочৎ m. 'young cicada'. He does not exclude, however, that the Greek word may be "an onomatopeic creation or borrowing from a hitherto unidentified external source” (Szemerényi 1988: p. 134). Beekes (2010: p. 696; 2014: p. 88) connects two Hesychian glosses (see 5.7 and 5.8), suggesting (perhaps correctly) that the attested Hesychian form kíkovৎ should be treated as a Pre-Greek borrowing.

If the lexeme kíkov m. 'young cicada' represents a Doric (or Aeolic) Greek formation, where the final ending -ovs corresponds to Attic-Ionic - $v \varsigma$, then the comparison of the Greek term in question with OInd. siśsh m. (u-stem) 'child, infant, the young of any animal', adj. 'young, infantine' (Monier-Williams 1999: p. 1076), ${ }^{11}$ as well as with Pali susu- m. 'lad', Prakrit sisu-, susu- m.n. 'id.', Oriya sisa m. 'son', Hindi sis, sisu m. 'young of any animal, infant', Singhalese susu 'child' (Turner 1966: p. 722), seems the most obvious explanation. In fact, OInd. š́śuh and other Indo-Aryan terms represent perfect equivalents of Doric (or Aeolic) Greek kíkovৎ not only from the phonological point of view, but also from the semantic one. The Hesychian Greek term kíkous and its probable Indo-Aryan equivalents go back to the Proto-Indo-European archetype * $k^{\prime} i-k^{\prime} u-s \mathrm{~m}$. ( $u$-stem) 'young animal; child, infant', adj. 'young, infantine', which derives by expressive reduplication from the root *keu- 'to swell / schwellen' (Pokorny 1959: pp. 592-594). The semantic change of 'young of any animal' to 'young cicada' seems to represent a purely Greek innovation.

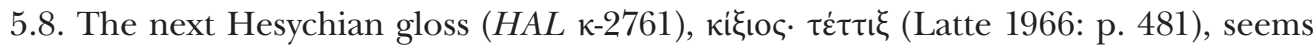
to be related to the Greek appellative discussed above (see 5.7). Gil Fernández (1959: p. 127) treats it as a variant of the earlier Hesychian gloss discussed under 5.7, containing an onomatopeic element *kik- or *gig-(possibly a reduplicated root like Lat. cicāda). He stresses, finally, that "[la] coincidencia del latín y del griego en este punto parece abogar por la hipótesis de un préstamo de una lengua mediterránea non ide.”. Beekes (2010:

11 The Sanskrit word in question frequently refers to young animals, e.g. OInd. śiśu-nāga- m. 'young snake; young elephant' vs. nāga- m. 'snake; elephant' (Monier-Williams 1999: p. 1076), OInd. śaśaka-siśs- m. 'the young of a hare' vs. śaśá-, dimin. śaśaka- m. 'hare' (Monier-Williams 1999: p. 1060). 
p. 696) represents a similar stance: "The variation $\kappa / \xi$ points to Pre-Greek origin". Alt-

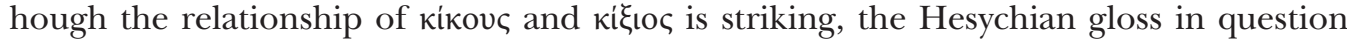
is unclear from the point of view of the Greek (and Indo-European) word-formation. It should be remembered, however, that the Indo-European suffix *-só- appears frequently in animal terminology, cf. OInd. vatsáh m. 'calf, young of any animal, offspring, child' (< PIE. *uet-só-s 'one-year-old animal, yearling') vs. Lat. vitulus m. 'calf, bull-calf', also 'foal' and 'seal, sea-calf' (< PIE. *uet- 'year'; Pokorny 1959: p. 1175). It also functions as an "Ad-

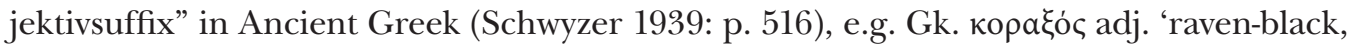

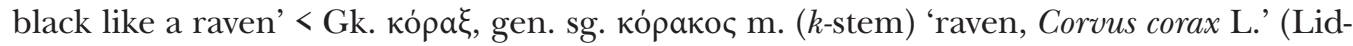
dell \& Scott 1996: p. 980; Montanari 2003: p. 1116). Theoretically, it cannot be excluded that Gk. (Hesych.) kíłıৎ (sc. $\tau \dot{\varepsilon} \tau \tau \iota \xi)$ is an innovative nominal formation derived from the

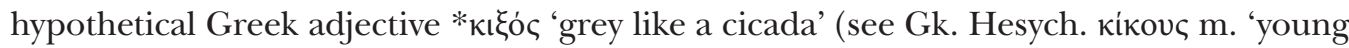

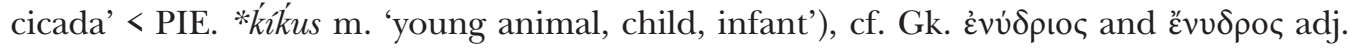

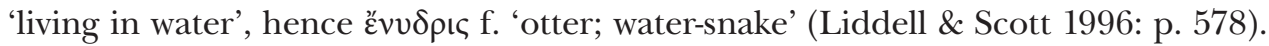

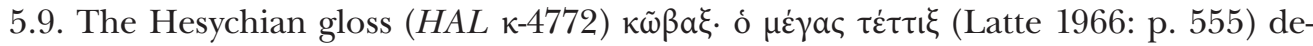
notes a 'big cicada' i.e. the adult male cicada, which chirps shrilly in hot and dry weather (Gil Fernández 1959: pp. 122-123; Davies \& Kathirithamby 1986: p. 132; Beavis 1988: p. 95). The lexeme in question is of onomatopoeic origin. It recalls the well known phrase

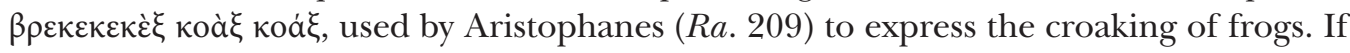
this interpretation is correct, the attested gloss should be read as * $\kappa \tilde{\omega} F \alpha \xi$ 'the croacker', i.e. 'the chirper'. ${ }^{12}$ The Hesychian gloss in question cannot be of Attic-Ionic origin.

It is worth emphasizing that the Attic form коá $\xi$ demonstrates the so-called metathesis quantitatis, as Proto-Greek * $\kappa \omega F \dot{~ a ́ \xi ~ ' l o u d ~ s o u n d ~(o f ~ f r o g s ~ o r ~ c i c a d a s) ' ~(s t a n d i n g ~ i n ~ a n ~ a c-~}$ centual opposition to $\kappa \tilde{\omega} \beta a \xi \mathrm{m}$. 'male chirping cicada') yields the Old Ionic form * $\kappa \omega \alpha \dot{\alpha}$, which regularly develops into (Attic-Ionic) коá́ł [ko'a:ks].

\section{Conclusions}

The Ancient Greek terminology denoting the 'cicada' is abundant and for the most part easily explainable. The results of our etymological analysis of the Hesychian terms can be presented as follows:

6.1. The adult male cicadas are generally named after their loud and pleasant voices.

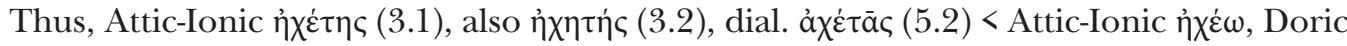

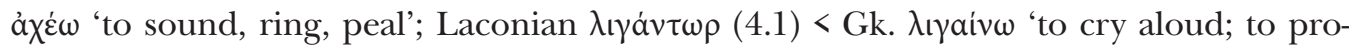
duce clear sounds on the pipe; to play on the pipe; to sing of'; Eleian $\beta$ áßakor 'adult

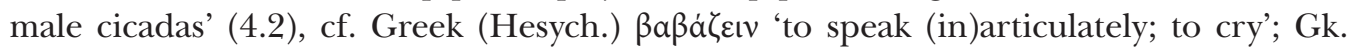

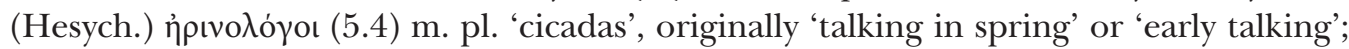
Gk. (Hesych.) $\kappa \tilde{\omega} \beta a \xi ~(5.9)$, originally 'croaker; chirper'.

6.2. As opposed to adult male cicadas (which usually utter a loud and unique sound), the female or young ones are mute by their nature. Some Greek appellatives refer to this

12 According to Beekes (2014: p. 88), "it is a Pre-Greek word". 
feature, e.g. Pamphylian $\sigma \nmid \gamma \bar{\alpha} \lambda \varphi$ oi m. pl. 'mute (young or female) cicadas' (2.4), see Attic-

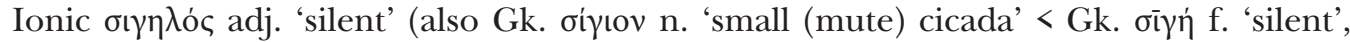
$\sigma \tilde{\imath} \gamma \alpha$ adv. 'silently'). It cannot be excluded that the Sidetic (or Pamphylian Greek) term

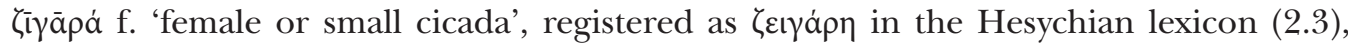

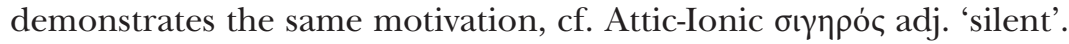

6.3. Cicadas are also named after the grey colour of their bodies: Cypr. кi $\lambda \lambda$ os m.

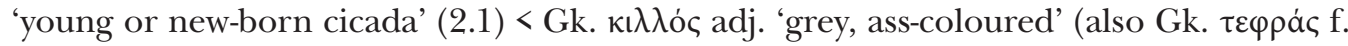

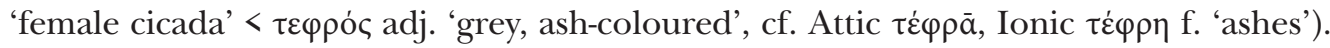

6.4. A number of terms for 'cicada' refer to plants among which cicadas, especially

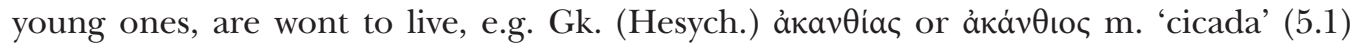

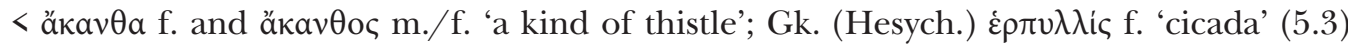

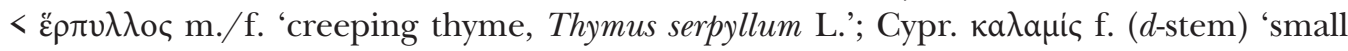

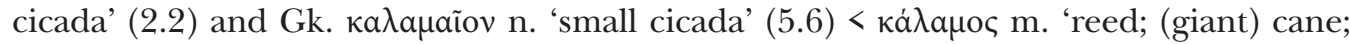
sweet flag'.

6.5. The basic name for 'tree-cricket, cicada' is $\tau \dot{\varepsilon} \tau \tau \bar{\imath} \xi$ ( $\gamma$-stem, also $\kappa$-stem) (3.4); it probably derives from the (Pre-)Greek adjective $\tau \varepsilon \sigma \sigma i \chi \chi^{\prime} \varsigma$ 'small'. The term seems to represent an onomatopeic item or perhaps a borrowing from an unidentified Pre-Greek language.

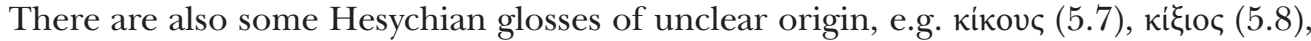

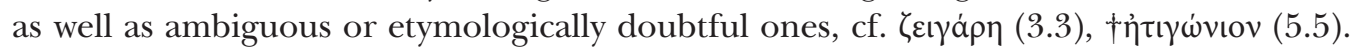
It cannot be excluded that these appellatives were borrowed by the Ancient Greeks from a foreign source, e.g. from a Mediteranean substratum or an Anatolian language spoken in Asia Minor.

\section{Bibliography}

Adrados, F. R. (Ed.). (1989). Diccionario griego-español (Vol. I). Madrid: Consejo Superior de Investigaciones Científicas.

Alessio, G. (1954). Relitti mediterranei nel greco e nel latino. Archivio Glottologico Italiano, 39, 92-101.

André, J. (1985). Les noms de plantes dans la Rome antique. Paris: Société d'Édition «Les Belles Lettres».

Andriotis, N. (1974). Lexikon der Archaismen in neugriechischen Dialekten. Wien: Verlag der Österreichischen Akademie der Wissenschaften.

Beavis, I. C. (1988). Insects and Other Invertebrates in Classical Antiquity. Exeter: University of Exeter. Beekes, R. (2010). Etymological Dictionary of Greek (Vol. I-II). Leiden - Boston: Brill.

Beekes, R. S. P. (2014). Pre-Greek. Phonology, Morphology, Lexicon. Leiden - Boston: Brill.

Brixhe, C. (1976). Le dialecte grec de Pamphylie. Documents et grammaire. Paris: Librairie d'Amérique et d'Orient Adrien-Maisonneuve.

Chantraine, P. (1977). Dictionnaire étymologique de la langue grecque (Vol. IV-1). Paris: Éditions Klincksieck.

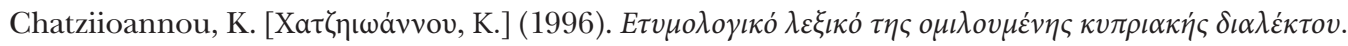

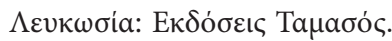


Cunningham, I. C. (2018). Hesychii Alexandrini Lexicon (Vol. I). Berlin - New York: Walter de Gruyter. Davies, M., \& Kathirithamby, J. (1986). Greek Insects. London: Gerald Duckworth \& Co. Ltd. Derksen, R. (2008). Etymological Dictionary of the Slavic Inherited Lexicon. Leiden - Boston: Brill.

Dihle, A. (1967). The Poem on the Cicada. Harvard Studies in Classical Philology, 71, 107-113.

Dressler, W. (1965). Pamphylisch -d- zu -r-: ein weiterer Substrateinfluss? Archiv Orientální, 33(2), 183-189.

Ebener, D. (1981). Die Griechische Anthologie in drei Banden (Vol. II). Berlin - Weimar: AufbauVerlag.

Egan, R. B. (1988). Two Complementary Epigrams of Meleager (A.P. VII 195 and 196). The Journal of Hellenic Studies, 108, 24-32.

Egetmeyer, M. (1992). Wörterbuch zu den Inschriften im kyprischen Syllabar. Berlin - New York: Walter de Gruyter.

Egetmeyer, M. (2010). Le dialecte grec ancien de Chypre (Vol. I). Berlin - New York: Walter de Gruyter.

García Ramón, J. L. (2007). Pamphylian. In H. Cancik, H. Schneider, \& C. F. Salazar (Eds.), Brill's New Pauly Encyclopedia of the Ancient World (Vol. X, pp. 418-419). Leiden - Boston: Brill.

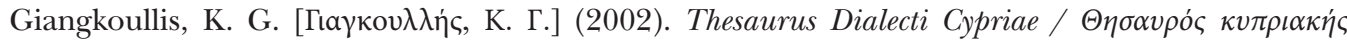

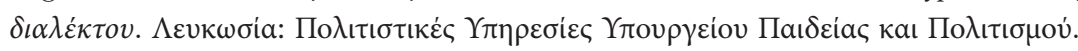

Gil Fernández, L. (1959). Nombres de insectos en griego antiguo. Madrid: Instituto "Antonio de Nebrija».

Guida, A. (2016). Aristofane Cavalieri 1331 e una glossa di Esichio. Prometheus, 42, 96-98.

Hansen, P. A. (Ed.). (2005). Hesychii Alexandrini Lexicon (Vol. III). Berlin - New York: Walter de Gruyter.

Hansen, P. A., \& Cunningham, I. C. (2009). Hesychii Alexandrini Lexicon (Vol. IV). Berlin - New York: Walter de Gruyter.

Kaczyńska, E., \& Witczak, K. T. (2017a). Modern Greek Terms for Amphibians in Crete. Eos, 104(1), 107-116.

Kaczyńska, E., \& Witczak, K. T. (2017b). Klaudiusz Elian o nazwach cykad [Claudius Aelian on Words for Cicadas]. Symbolae Philologorum Posnaniensium, 27(2), 41-53.

Kroonen, G. (2013). Etymological Dictionary of Proto-Germanic. Leiden - Boston: Brill.

Latte, K. (1953). Hesychii Alexandrini Lexicon (Vol. I). Hauniae: Ejnar Munksgaard.

Latte, K. (1966). Hesychii Alexandrini Lexicon (Vol. II). Hauniae: Ejnar Munksgaard.

Lehmann, W. F. (1986). A Gothic Etymological Dictionary. Leiden: E. J. Brill.

Liddell, H. G., \& Scott, R. (1996). A Greek-English Lexicon (with a revised supplement). Oxford: Clarendon Press.

Metri, P. (1954). Il dialetto panfilio. Rendiconti dell'Istituto Lombardo di Scienze e Lettere, 87, 79-116.

Meyer-Lübke, W. (1935). Romanisches etymologisches Wörterbuch. Heidelberg: Carl Winter.

Monier-Williams, M. (1999). A Sanskrit-English Dictionary. Delhi: Motilal Banarsidass Publishers.

Montanari, F. (2003). Vocabolario della lingua greca. Milano: Loescher Editore.

Niedermann, M. (1919). Die Namen des Storches im Litauischen. In Festgabe Adolf Kaegi von Schülern und Freunden, dargebracht zum 30. September 1919 (pp. 66-92). Frauenfeld: Huber \& Co.

Pokorny, J. (1959). Indogermanisches etymologisches Wörterbuch. Bern - München: Francke Verlag.

Schenkl, F., \& Brunetti, F. (1991). Dizionario greco-italiano, italiano-greco. Genova: Casa del libro Fratelli Melita. 
Schmidt, M. (1860). Hesychii Alexandrini Lexicon (Vol. II). Ienae: Sumptibus Frederici Maukii.

Schmidt, M. (1862). Hesychii Alexandrini Lexicon (Vol. IV, Pars I). Ienae: Sumptibus Frederici Maukii. Schwyzer, E. (1939). Griechische Grammatik (Vol. I). München: C. H. Beck.

Shipp, G. P. (1979). Modern Greek Evidence for the Ancient Greek Vocabulary. Sydney: Sydney University Press.

Strömberg, R. (1943). Studien zur Etymologie und Bildung der griechischen Fischnamen. Göteborg: Elanders Boktryckeri Aktiebolag.

Strömberg, R. (1944). Griechische Wortstudien. Untersuchungen zur Benennung von Tieren, Pflanzen, Körperteilen und Krankheiten. Göteborg: Elanders Boktryckeri Aktiebolag.

Szemerényi, O. (1988). Etyma Latina V (26-31). In N. Horsfall (Ed.), Vir bonus discendi peritus: Studies in Celebration of Otto Skutsch's Eightieth Birthday (pp. 128-134). London: University of London, Institute of Classical Studies.

Thumb, A., \& Scherer, A. (1959). Handbuch der griechischen Dialekte (Teil II). Heidelberg: Carl Winter.

Tichy, E. (1983). Onomatopoetische Verbalbildungen des Griechischen. Wien: Verlag der Österreichischen Akademie der Wissenschaften.

Trautmann, R. (1923). Baltisch-Slavisches Wörterbuch. Göttingen: Vandenhoeck \& Ruprecht.

Turner, R. L. (1966). A Comparative Dictionary of the Indo-Aryan Languages. London: Oxford University Press.

de Vaan, M. (2008). Etymological Dictionary of Latin and the Other Italic Languages. Leiden - Boston: Brill.

Wartelle, A. (2000). Brèves remarques de vocabulaire grec. Revue des Études Grecques, 113, 211-219.

dr hab. Elwira Kaczyńska prof. nadzw. UŁ / elwira.kaczynska@uni.lodz.pl

Chair of Classical Philology

University of Lodz, Faculty of Philology

Pomorska 171/173, 90-236 Łódź, Poland

Prof. dr. hab. Krzysztof Witczak / krzysztof.witczak@uni.lodz.pl

Department of Linguistics and Latin Studies

University of Lodz, Faculty of Philology

Pomorska 171/173, 90-236 Łódź, Poland

Toto dílo Ize užít v souladu s licenčními podmínkami Creative Commons BY-SA 4.0 International (https://creativecommons.org/licenses/by-sa/4.0/legalcode). Uvedené se nevztahuje na díla či prvky (např. obrazovou či fotografickou dokumentaci), které jsou v díle užity na základě smluvní licence nebo výjimky či omezení př́slušných práv. 
